\title{
Stabilization policy of the state in the post-pandemic period
}

\author{
Armen Altunyan ${ }^{1}$, Tatiana Kotcofana $^{1 *}$, and Anastasiya Titova ${ }^{1}$ \\ 1 Saint-Petersburg State University, Faculty of Economics, Universitetskaya emb. 7-9, Saint- \\ Petersburg, Russia
}

\begin{abstract}
Research background: The coronavirus pandemic, which has affected all spheres of society and the economy, has formed new realities and conditions for modern world development. The governments of many countries have faced a choice of how to combine the security of citizens ' lives and the need to resist the decline in production, employment, and income.

Purpose of the article: The main purpose of the presented article is to study the instruments of stabilization policy during the pandemic and postpandemic economy and to identify measures aimed at reorienting from ensuring monetary and budgetary stability to expanding effective demand and stimulating the economy.

Methods: To conduct the study, we used official statistics data, the analysis of which allowed us to determine the degree of mutual influence of key parameters of economic development.

Findings \& Value added: The results show that in developed countries, support measures by monetary policy instruments are limited, so for the most part, fiscal mechanisms to support the population and business are implemented. In Russia, the opportunities to soften monetary policy with traditional monetary policy measures still retain some effectiveness. However, the current economic policy imposes a forced type of consumer behavior based on making financial decisions in the absence of choice, so such decisions form negative consequences - indebtedness and poverty. In this regard, recommendations are given for the implementation of stabilization policy instruments aimed at reorienting it from ensuring monetary and budgetary stability to stimulating the Russian economy and expanding the monetary base of demand.
\end{abstract}

Keywords: stabilization policy; monetary and budgetary policy; monetary and budgetary stability

JEL Classification: E52; E62; E64

\footnotetext{
* Corresponding author: t.kotsofana@spbu.ru
} 


\section{Introduction}

The 2020 coronavirus pandemic, which is a crisis in the global economy, has exacerbated existing contradictions and served as a catalyst for growing change. The shock of the pandemic veiled the approaching cyclical crisis of the world economy associated with the growth of its debt burden and the presence of inflating "bubbles" in the markets of financial assets of high-tech companies.

The picture of a post-pandemic world, in which different political and economic systems confront, inclines to the search for a new pragmatic model based on holistic economic theory and practical economic policies aimed at ensuring sustainable growth with poverty reduction and improving the quality of life. The main causes of the current economic situation lie outside the economic sphere, but it is overlaid on unresolved problems that have accumulated before the pandemic. As a result, even a variety of measures to support the economy give only a slight revival, while preserving structural problems.

Under these conditions, the market reaction does not meet traditional expectations. On the one hand, with an increase in the supply of money in the economy, low interest rates do not lead to an increase in investment, on the other hand, with an increase in liquidity in the economy, there has been no depreciation of the dollar and there is a record growth in the stock markets, which after an economic downturn can lead to further inflating of the "financial bubble". Against this background, the gap between growing incomes from property and stagnant incomes from labor has widened. Thus, soft monetary policy, in the conditions of dwindling demand and low propensity to invest, has exacerbated issues of social inequality.

The level of uncertainty during the pandemic was similar to the period of the Great Depression of 1929-1933. According to the the research of Altig et al. (2020), all indicators show huge uncertainty jumps in reaction to the pandemic and its economic fallout. However, the nature of competition on the global market under the New Economy is quite more complicated (Pashkus et al., 2018), and there are a number of factors aggravating this situation: a drop in economic activity even before the pandemic, high levels of public debt in developed countries and low interest rates that limit the possibilities of monetary regulation, reinforcing the political and economic confrontation of world powers. The scale of the current crisis in the conditions of destruction of production and trade and economic ties in the general structure of the modern international division of labor threatens the existing modern model of globalization, creates risks of uncertainty of development in the near future. COVID restrictions can reduce current-period GDP by more than is directly associated with the restrictions themselves when rigid capital costs induce firm exit. Higher inequality is associated with larger restriction multipliers. The effectiveness of fiscal policies depends on inequality and the joint distribution of capital operating costs and firm revenues. Furthermore, COVID19 restrictions can cause future inflation, as households tilt their expenditure toward the future (Auerbach et al., 2021)

\section{Methods}

The methodological basis of the research is the dialectical materialistic and concrete historical method. At the same time, the dialectical-materialistic approach is the initial principle of research. As applied to this study, this means that, on the one hand, the dialectical method allows to know the essence and causes of the processes considered in the most adequate reflection of their dynamic integrity, on the other hand, any theoretical research should be supported by historical practice and statistical data. In this regard the empirical basis of the analysis is statistical materials and specific economic and statistical studies. 


\section{Results and Discussions}

\subsection{Impact of the coronacrisis on the global and Russian economy}

The world approached the current crisis with the same conditions as in the previous (20072009) crisis: a policy of quantitative easing, providing a slight revival of the economy while maintaining huge state and corporate debts, an intensifying geopolitical struggle with the use of international economic sanctions. Restrictive measures caused by the coronavirus pandemic have led to a decline in GDP, a contraction in domestic demand and an increase in unemployment.

The decline of the Russian economy in 2020 by 3.1\% was less than in many other countries, the decline in the United States, Germany, France and Japan reached from -4 to $9 \%$. This circumstance is explained by Russia's less involvement in global economic relations, the widespread use of administrative levers of influence on economic processes, a significant share of the public sector, with a small share of small and medium-sized businesses and a smaller share of services in the structural part of GDP. Measures to support the Russian economy, estimated at about $5 \%$ of GDP, are significantly less than in the leading countries, where they reached $10-50 \%$ of GDP.

For Russia, the current situation is exacerbated by the accumulated structural problems in the economy, the intertwining of serious problems on the side of both demand and supply. On the demand side, the deterioration of the terms of trade for Russia as an external factor and the fall in the welfare of the population, increasing social inequality, low political confidence of the population in the government, as an internal factor. On the supply side, there will be a reduction in the available capital and labor resources in the face of business closures due to the pandemic. The development of mechanisms for long-term economic growth is associated with the choice of the optimal model of economic development, taking into account restrictions on capital and labor resources. But countering the combination of supply and demand shocks requires, in fact, the adoption of opposite measures. In the face of falling demand, based on the experience of the Great Depression of the 1930s, it is necessary to use monetary stimulus. In the context of supply shock, as the experience of the crisis of the 1970s shows, monetary stimulus threatens stagflation. But the choice of the right economic policy for all times in isolation from specific circumstances is impossible. Comparison of the crisis of 2020 with the Great Depression is possible on the scale of the fall of economies. As for the reasons, the crisis of 2020 was based on supply factors and this is the main difference between it from the Great Depression of the 1930s, and from the Great Recession of 2008-2009. The restriction of the production of goods and services is not compensated by cash injections, since inflation may follow, and then stagflation.

\subsection{Opportunities and Limitations of Monetary Policy}

The instruments of stabilization policy in the post-pandemic economy are becoming more diverse and extraordinary. Monetary policy support measures are limited. This circumstance can be explained by the steady deflation formed in recent years, caused by the expanding process of globalization and digitalization of economies, the weak relationship between inflation and production growth in connection with the transition to the inflation targeting regime, the decrease in the neutral level of the real rate in developed countries, limiting the possibilities of interest rate policy (Goryunov et al., 2021). Central banks as priority goals began to determine for themselves the reduction of inflation with the simultaneous limitation of monetary measures to stimulate economies, as well as the financing of the state budget deficit through additional emission, which seemed a necessary necessity. Monetary policy instruments are generally weak in the context of the pandemic. For developed countries, 
additional cash injections are not able to stimulate investment as a result of further interest rate cuts and quantitative easing policies. Moreover, monetary policies are presently close to a liquidity trap combined with weakened transmission links to the real economy (Braunerhjelm, 2021). In emerging economies, the potential for lower interest rates exists, but this may not lead to an increase in lending in the economy due to the reduced impact of interest rate dynamics on investment and output caused by high levels of uncertainty.

This is also confirmed by econometric studies. So, Chudik et al., (2021) showed with a threshold-augmented Global VAR, that, firstly, fiscal policy is playing a key role in mitigating the effects of the pandemic; secondly, all else equal, countries that implemented larger fiscal support are expected to experience less output contractions.

As a result, aggregate demand in developed economies, where there is a manifestation of the "liquidity trap", and in developing countries we are faced with the action of the "risk trap" (Buklemishev et al., 2021), can be mainly by fiscal policy measures, rather than monetary policy. In this regard, fiscal mechanisms are being implemented to support the population and business. In many countries, the volume of budget support for the economy is greater than the funds received through monetary instruments.

In recent years, Russia has pursued a moderately tight financial and monetary policy in Russia, expressed in a moderate increase in the monetization coefficient of the economy, in reducing budget expenditures, in reducing inflation rates, in maintaining the interest rate on loans for sectors of the real sector of the economy above the level of profitability, does not contribute to the expansion of domestic demand and the rise in economic activity. According to Ershov M. (2019), the rigidity in monetary and financial policy (including the increase in VAT) leads, in particular, to an increase in prices and mortgage rates, thereby limiting opportunities for business activity and hampering the economic growth.

The main factor in the decline in inflation was the reduction in domestic demand. The Central Bank does not show interest in the growth of consumer demand, it continues to consider the growth of domestic demand as a pro-inflationary factor. In order to reduce inflation, the Bank of Russia artificially restrains domestic demand, both consumer and investment. This hinders the economic recovery. As one of the arguments for increasing domestic consumer demand, the Central Bank indicates the deferred funds of citizens due to the reduction of foreign tourism. The Bank of Russia considers inflation as an immediate goal of monetary policy. The Central Bank's policy of targeting inflation is a brake on economic growth and ultimately dooms the Russian economy to a prolonged recession. It is necessary to expand the offer of credit at affordable interest rates. Of course, increasing the availability of credit and resolving the issue of additional monetization of the Russian economy is not the only, although the most important problem of monetary policy.

The main difficulties are in the weak permeability of money from banks to the real economy. Monetary liquidity, provided to banks in excess and on favorable terms, does not go to the real sector. Entrepreneurs and the banking sector are experiencing risks due to high debt in all sectors of the economy in the absence of prospects for demand growth caused by falling incomes of the population.

\subsection{Structural problems of the Russian economy}

Stagnation, recession of the Russian economy is connected, among other things, with a very low rate of accumulation, which does not allow to reach sustainable economic growth (Vlasov et al., 2020). In Russia, gross accumulation is lower than gross savings, the gap is from 6 to $10 \%$. GDP (see Table 1). This is the result of insufficiently effective work of banks on investment lending to the economy. A high propensity to save on the part of the population gives a negative effect on the investment multiplier. This situation has developed in our country due to the low level of trust on the part of most people to commercial and state 
structures, many people are not sure of their future and prefer to save money "for a rainy day". The mechanism of monetary transmission to the real economy has not been established, which could increase the role of internal factors for economic growth.

The problem of insufficient and decreasing efficiency of investments is associated with a structural feature of the Russian economy: the dominance of big business, unfavorable business and investment climate. At the same time, the mechanisms for redistributing the money supply are such that money is concentrated in a limited circle of legal entities and individuals, without flowing into those industries and to those players who really need them. Although, in theory, it depends on monetary policy whether those sectors that really need to update production capacities will receive money.

Table 1. GDP, Gross savings to GDP\%, Gross fixed capital formation in \% of GDP, investments in fixed assets to GDP \%.

\begin{tabular}{|c|c|c|c|c|c|c|c|}
\hline & $\mathbf{2 0 1 4}$ & $\mathbf{2 0 1 5}$ & $\mathbf{2 0 1 6}$ & $\mathbf{2 0 1 7}$ & $\mathbf{2 0 1 8}$ & $\mathbf{2 0 1 9}$ & $\mathbf{2 0 2 0}$ \\
\hline GDP in billions of rubles & 79030 & 83087 & 85616 & 91843 & 103861 & 109241 & 106967 \\
\hline Gross savings as \% of GD & 30,2 & 30,5 & 28,2 & 28,9 & 31,9 & 30,5 & 29,8 \\
\hline $\begin{array}{c}\text { Gross accumulation as a \% of } \\
\text { GDP }\end{array}$ & 22,4 & 22,1 & 23,1 & 23,8 & 21,9 & 22,7 & 23,9 \\
\hline $\begin{array}{c}\text { Gross fixed capital formation } \\
\text { as a \% of GDP }\end{array}$ & 21,4 & 20,6 & 21,9 & 22,0 & 20,6 & 21,1 & 21,7 \\
\hline $\begin{array}{c}\text { Investments in fixed assets as } \\
\text { \% of GDP }\end{array}$ & 17,6 & 16,7 & 17,2 & 17,4 & 17,1 & 17,6 & 18,8 \\
\hline $\begin{array}{c}\text { Investments in fixed assets in } \\
\text { \% to the previous year }\end{array}$ & $-1,5$ & $-10,1$ & $-0,2$ & 4,8 & 5,4 & 2,1 & $-1,4$ \\
\hline $\begin{array}{c}\text { Degree of depreciation of } \\
\text { fixed assets in \% at the end of } \\
\text { the year }\end{array}$ & 49,4 & 47,7 & 48,1 & 47,3 & 46,6 & 37,8 & 38,0 \\
\hline
\end{tabular}

Source: http://gks.ru/free_doc/new_site/vvp/vvp-god/tab24.htm

Russia has a consolidated and simplified structure of the economy, when several large banks lend to several large companies. Large commercial banks, which are mainly stateowned, receive high excess profits, due to the high difference between interest rates on loans and deposits. In the Russian banking system, a contradictory situation is developing, when, on the one hand, the real sector of the economy, creating added value, suffers losses, and on the other hand, the financial sector receives super profits. Another source of super-profits of banks is lending to individuals, in which interest rates far exceed the growth rate of incomes of the population. As a result, it turns out that the source of super-profits of banks are working capital of enterprises and money withdrawn from citizens through loans.

And the actives of Russian banks as of January 1, 2021 reached 103.7 trillion rubles, since the beginning of the year they have grown by almost 15 trillion rubles, or by $16.8 \%$. The real sector of the Russian economy is not developing, because there are not enough financial resources for investment. The state needs to attract private investment and carry out its own in the real sector of the economy to ensure GDP growth and real incomes of the population. In the conditions of economic recession, we observe an increase in both retail and corporate lending caused by preferential state programs (mortgages at $6.5 \%$ and business loans at $2 \%$ ), a general decrease in market rates and customer demand for debt restructuring. This is the main difference between the effect of the current crisis and the crisis of 2014. 


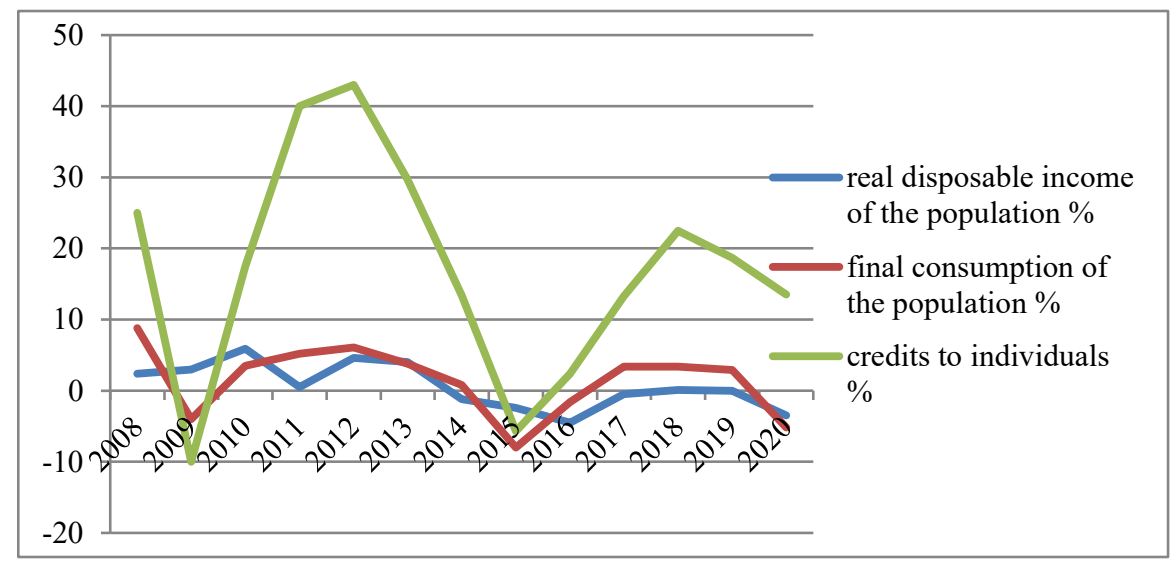

Figure 1. Dynamics of consumer demand, real incomes of the population and loans to individuals in $\%$ to the previous year.

According to the Central Bank of the Russian Federation, the volume of loans to individuals increased in 2020 by $13.5 \%$ and amounted to 20 trillion. rubles, compared to a year earlier, when the growth was by $18.6 \%$ (see Fig. 1). The growth rate slowed down mainly due to a decrease in unsecured consumer lending, in which the highest risks are concentrated. The volume of loans to legal entities increased by $9.9 \%$ and amounted to 44.8 trillion rubles, compared to a year earlier, the portfolio of loans to enterprises increased by $5.8 \%$. The growth of lending to enterprises in 2020 helped companies to go through the acute phase of the economic crisis. The total volume of deposits and funds of organizations in accounts for 2020 increased by $15.9 \%$ to 32.6 trillion rubles (see Table 2).

Table 2. The main indicators of the banking sector of Russia for 2013-2020.

\begin{tabular}{|c|c|c|c|c|c|c|c|c|}
\hline Index Year & 2013 & 2014 & 2015 & 2016 & 2017 & 2018 & 2019 & 2020 \\
\hline $\begin{array}{c}\text { Assets of banks to GDP, } \\
\%\end{array}$ & 86,8 & 108,7 & 99,7 & 93,0 & 92,5 & 90,8 & 88,4 & 96,9 \\
\hline $\begin{array}{c}\text { Share of loans to the } \\
\text { economy in GDP, \% }\end{array}$ & 49,0 & 57,2 & 52,8 & 47,7 & 45,6 & 46,5 & 47,0 & 60,6 \\
\hline $\begin{array}{c}\text { Share of loans to the } \\
\text { economy in the assets of } \\
\text { banks, \% }\end{array}$ & 56,5 & 52,6 & 52,9 & 51,3 & 49,1 & 51,3 & 53,2 & 62,5 \\
\hline $\begin{array}{c}\text { Profit of the banking } \\
\text { sector in billion rubles }\end{array}$ & 993,5 & 589,1 & 191,9 & 929,6 & 789,6 & 1344,8 & 2036,0 & 1909,7 \\
\hline
\end{tabular}

Source: Bulletin of Banking Statistics 2014,2015,2016,2017,2018,2019,2020,2021.

For the banking sector, the focus on high margins on credit and deposit operations, a freely floating exchange rate and a narrowing of the money supply, in order to target inflation, favors high profits. The banking system does not perform the function of redistribution of money and is able to provide only current activities, but not long-term. The presence of a structured developed and competitive financial sector is a prerequisite for achieving a consistently low rate of price growth. From the point of view of creating conditions for sustainable economic growth, the current state of the relationship between the financial flows of the banking sector and cash flows in the real sector can be assessed as insufficiently effective. A serious problem of the Russian economy is the separation of the banking system from the real economy, the weak participation of financial flows of the banking sector in 
economic growth. Credit institutions are mainly aimed at carrying out banking operations of a speculative nature.

So, according to the results of work for 2020, the most profitable bank was Sber, whose profit amounted to 1.1 trillion. At the same time, the amount of state support for the entire agricultural sector amounted to 302 billion rubles in 2019. Now it includes the companies "Sberlogistika", "SberMarket" and "Scooter", food delivery services, taxi and car sharing, Delivery Club, "Kitchen in the district", "Citymobil" and You Drive, services in health care ("SberZdorovie") and services b2b. For the management of Sberbank, it is not so much the commercial success of the ecosystem companies that is important, but full control over them.

But only the instruments of monetary policy will not solve the problem of economic growth. In 2016-2019, the volume of taxes accrued for payment annually grew by 2.5-3.9 trillion rubles. the Tax burden increased significantly with the transition to the calculation of property tax on individuals at cadastral value, for legal entities since 2019 the TAX RATE on VAT has increased from $18 \%$ to $20 \%$. In conditions of stagnation and recession, the tax burden on business increases, as a result, the profitability of enterprises decreases and the purchasing power of the population falls. In 2021, the taxation of individuals is tightened, relating not only to the incomes of citizens, but also to their savings. Despite the fall in incomes, there is a noticeable increase in the loan portfolio of the population, especially on mortgages, which will lead to an increase in interest expenses of the population and a decrease in real disposable incomes. Declining consumer demand will be reflected in a decrease in investment demand. To stimulate economic growth at the recovery stage, it would be advisable to consider reducing the tax burden on the payrot, which would stimulate the growth of average incomes of citizens to increase the investment activity of enterprises. To maintain consumer demand, it would be correct to establish a non-taxable minimum on the incomes of individuals, at least at the level of the subsistence minimum, as it is in other countries with socially oriented economies.

Current economic policy imposes a forced type of consumer behavior based on financial decision-making in the absence of choice, so such decisions form negative consequences debt and poverty. Increased wealth inequality can lead to economic and social upheaval. The National Security Strategy of the Russian Federation highlights the threat of increasing the differentiation of the population by income level. Russia is one of the world leaders in wealth inequality: $10 \%$ of the population accounts for $77 \%$ of all wealth, and $56 \%$ is in the hands of 1\%. (Kulikov, 2020). Moreover, the study (Kartaev et al., 2020) shows that the decrease in annual inflation from double digits to the target of the Bank of Russia did not contribute to the mitigation of inequality, but rather aggravated it. Meanwhile, a study (Wildman, 2021) shows that countries with high levels of income inequality have performed significantly worse in the fight against the COVID-19 outbreak in terms of cases and deaths. The results demonstrate a significant positive association between income inequality and COVID-19 cases and death per million in all estimated models. A $1 \%$ increase in the Gini coefficient is associated with an approximately $4 \%$ increase in cases per-million and an approximately $5 \%$ increase in deaths per-million.

According to Rosstat, the share of Russians with incomes below the subsistence minimum decreased from $12.3 \%$ in 2019 to $12.1 \%$ in 2020 . The total number of poor Russians by the end of 2020 amounted to 17.8 million (Rambler.News, 2021).

The scale of poverty in Russia is very low. Poverty in the Russian Federation has its own specifics and features, expressed mainly by the economic and financial policy of the government. In the fight against poverty, one of the main goals of Russia's development, defined by the "May" presidential decree, should be to reduce the poverty rate from $12.5 \%$ in 2018 to $6.6 \%$ in 2024 . To assess poverty in Russia, an absolute indicator based on the subsistence minimum is used. According to the methodology of the Organization for Economic Cooperation and Development, the poor include people whose incomes are below 
$60 \%$ of the median salary - the amount of wages below and above which the same number of employees receive income. In 2020, 24.6 percent of Russians (36 million people) had an income below 60 percent of the median, almost a quarter of citizens can be classified as lowincome. According to the results of the first quarter of 2021, the debt burden of Russians, which is the ratio of all loan payments to the total income of the population, increased to $11.9 \%$. This was caused by the growing debt on loans in the context of the pandemic with falling incomes of the population. At the same time, despite the high growth rates of mortgage lending, the contribution of mortgages to the increase in the debt burden was compensated by a decrease in mortgage rates.

The increase in the number of poor people is associated with a reduction in the real income of the population and with an increase in its debt burden. In the conditions of stagnating incomes of the population, it seems difficult to stimulate economic growth. Under the current situation, the country's economy is operating at half capacity due to the lack of credit for financing of working capital and investments in fixed assets. The reduction in inflation was achieved at the cost of suppressing the final demand from the impoverished population and enterprises that stopped investing. A study by Coibion et al. (2017) showed that contractionary monetary policy systematically increases inequality in labor earnings, total income, consumption and total expenditures. Similar results were obtained by Ybrayev (2021). Wealthy households (represented by the top $10 \%$ of the income distribution), who are more able to save in foreign currencies, gain in purchasing power of their incomes by hedging against domestic inflation.

At the same time, the poor households (represented by the bottom fifty percent of the income distribution) retain a larger share of liquid assets denominated in domestic currency, thus experiencing a greater burden of local currency inflation. He also shows that contractionary monetary policy is associated with periods of higher income inequality in emerging markets that is likely to exacerbate the damaging impact of inflation on the bottom groups of the income distribution.

To maintain a minimum level of consumption, the population is forced to resort to consumer lending, which leads to an increase in the cost of current consumption, and in conditions of falling incomes exacerbates the already plight of citizens. As a result, a vicious circle is formed: poverty reproduces and exacerbates poverty, reducing consumption and compressing aggregate demand. Against the background of a protracted drop in incomes of the population, people have less and less free money, and a relatively large part goes to servicing debts. In 2020, the average level of debt load of the population increased from 47.1 to $49.1 \%$. The total amount of debt of individuals to banks reached 18.5 trillion. Rubles.

But a slight increase in household spending against the background of declining incomes can be caused by pent-up demand and redistribution of the credit burden of the population from mortgage loans to higher consumer loans. This could draw the population into a protracted phase of the structural crisis. The anti-crisis measures taken undoubtedly had a positive impact on the dynamics of incomes, but whether they can radically change the situation raises some doubts. Growing inequality in income distribution, which implies an increase in the propensity to save the rich part of the population and a decrease in consumer demand from the poor, leads to long-term stagnation. For developed countries, with a high debt burden, the ability to stimulate aggregate demand through fiscal policy measures is reduced. For the Russian economy with low standards and the structure of household consumption and underfunding of investment projects, the post-China recommendations are very significant and relevant. The transition to economic growth requires maintaining demand, and in this respect Keynesian ideas remain in demand in Russia (Ryazanov, 2016).

Russia, having huge financial resources: budget surplus; stable oil prices in recent years; the national welfare fund (NWF), which has reached $8 \%$ of GDP, cannot provide stable economic growth of $4-5 \%$ per year. 


\section{Conclusions}

Economic development is not an end in itself. The meaning of economic policy is to increase the welfare and growth of real incomes of the population. In the national financial system, in conditions of poor development of market institutions, a high share of monopolization of the economy, the transmission mechanism works poorly and the potential for strategic management is lost. At the macro level, conditions are created for reducing investments in fixed assets, falling incomes of the population and slowing down economic growth. Budget policy, in particular, the "budget rule", contributes to the formation of low growth rates of the Russian economy, due to which extra, excess resources are withdrawn from the Russian economy to prevent its overheating, increase demand for imports and smooth out other negative effects of the Dutch disease.

The current measures of fiscal and monetary policy are aimed at limiting aggregate demand and, accordingly, the opportunities for economic growth. With strong state participation, it is possible to reorient monetary and fiscal policies from ensuring monetary and budgetary stability to stimulating the Russian economy (Kulikov, 2020). Felipe and Fullwiler (2021) show that once one knows how modern central banks manage monetary policy (i.e. through a corridor interest rate targeting system), and how they coordinate their daily operations with their Treasuries, monetization does not occur as it is often described, and it is not nearly as dangerous as its critics argue (and not as useful as its supporters claim). They clarify this by the examples of the Philippines, Singapore, and the People's Republic of China.

The potential for the rise of the Russian economy exists, but ideological disunity in theoretical approaches prevents it. It is necessary to learn from reality, and not to rely on a theory divorced from reality. In such a situation, taking into account the peculiarities of the Russian economy, it seems most adequate

- to build economic policy at the level of macroeconomic planning. Development policy is a combination of planning with market self-organization.

- It is advisable for the Central Bank to adhere to the linkage of the possible range of inflation and economic growth. It becomes fundamental not just a decrease in inflation, but an increase in investment activity due to the credit component.

- It is necessary to expand the monetary base of demand. The restoration of aggregate demand requires consistent measures in different directions: to establish a nontaxable minimum on the incomes of individuals, at least at the level of the subsistence minimum, to stimulate the growth of average incomes of citizens, reducing taxes on wage fund, to make a progressive taxation system not symbolic, but an effective measure.

- for the period of recovery of economic growth, abandon the excessive conservative "budget rule", increase budget spending and increase public debt for the sake of investment in education, health care and other structural reforms. The amount of increase in budget expenditures should be approximately equal in volumes aimed at increasing budget investments and real cash incomes of the population.

\section{References}

1. Altig, D., Baker, S., Barrero, J. M., Bloom, N., Bunn, P., Chen, S., Davis, S. J., Leather, J., Meyer, B., Mihaylov, E., Mizen, P., Parker, N., Renault, T., Smietanka, P., \& Thwaites, G. (2020). Economic uncertainty before and during the COVID-19 pandemic. Journal of Public Economics, 191, 104274. 
2. Pashkus, V.Y., Pashkus, N.A., \& Koltsova, A.A. (2018). Breakthrough positioning of innovative products in the global economy: Approaches and problems. Globalization And Its Socio-Economic Consequences, 2282-2290.

3. Auerbach, A. J., Gorodnichenko, Y., \& Murphy, D. (2021). Inequality, fiscal policy and COVID19 restrictions in a demand-determined economy, European Economic Review, $137,103810$.

4. Goryunov, E.L., Drobyshevskiy, S.M., Mau, V.A., \& Trunin, P.V. (2021). Chto my (ne) znaem ob effektivnosti instrumentov DKP v sovremennom mire? Voprosy Ekonomiki, 2, 5-34.

5. Braunerhjelm, P. (2021). Rethinking stabilization policies; Including supply-side measures and entrepreneurial processes. Small Business Economics.

6. Chudik, A., Mohaddes, K., \& Raissi, M. (2021). Covid-19 fiscal support and its effectiveness, Economics Letters, 205, 109939.

7. Buklemishev, O.V., Zubova, E.A., Kachan, M.N., Kurovskij, G.S., \& Lavrent'eva, O.N. (2021). Makroekonomicheskaya politika $v$ epohu pandemii: chto pokazyvaet model' ISLM? Voprosy Ekonomiki, 2, 35-47.

8. Ershov, M. (2019) Russian economic prospects with low inflation. Mirovaya Ekonomika i Mezhdunarodnye Otnosheniya, 63(8), 29-38.

9. Vlasov, S.A., \& Sinyakov, A.A. (2020). Effektivnost' gosudarstvennyh investicij i vyvody dlya denezhno-kreditnoj politiki v Rossii. Voprosy Ekonomiki, 9, 22-39.

10. Kulikov, N.I. (2020). Monetarnaya finansovaya i denezhno-kreditnaya politika gosudarstva i ee vliyanie na uroven' dohodov i snizheniya bednosti naseleniya Rossii, Finansy i Kredit, 26(5), 964-990.

11. Wildman, J. (2021). COVID-19 and income inequality in OECD countries. European ournal of Health Economics, 22, 455-462.

12. Rambler.News (2021). https://news.rambler.ru/sociology/46250290-deripaskaraskritikoval-dannye-rosstata-o-

bednosti/?utm_source=copysharing\&utm_medium=social

13. Coibion, O., Gorodnichenko, Y., Kueng, L., \& Silvia, J. (2017). Innocent Bystanders? Monetary policy and inequality. Journal of Monetary Economics, 88, 70-89.

14. Ybrayev, Z. (2021). Distributional consequences of monetary policy in emerging economies: Dollarization, domestic inflation, and income divergence. Comp Econ Stud,

15. Ryazanov, V. T. (2016) Kejnsianskaya ekonomicheskaya teoriya i politika: vozmozhnosti i ogranicheniya na sovremennom etape, Vestnik S.-Peterb. un-ta. Ekonomika, 2, 3-26.

16. Kulikov, N. I. (2020) Pochemu finansovaya i denezhno-kreditnaya politika gosudarstva ne privodit k rostu ekonomiki? Finansy $i$ kredit, 26(7), 1496-1521.

17. Kartaev, P.S., Klachkova, O.A., \& Lukianova, A.S. (2020). How does inflation influence income inequality in Russia? Voprosy Ekonomiki, 4, 54-66.

18. Felipe, J., \& Fullwiler, S. (2021). How 'monetization' really works - examples from three asian nations' responses to Covid-19. Review of Political Economy. 